\title{
TEACHERS' MOTIVATION TO PARTICIPATE IN INTERNAL AUDIT AS A FACTOR OF EDUCATIONAL QUALITY
}

\author{
Liudmila Rupšienė, Vilija Targamadzè \\ Klaipéda University, Klaipéda, Lithuania
}

Liudmila Rupšienè. Doctor of Social Sciences (Education). Professor of Department of Social Pedagogy, Klaipeda University, Faculty of Pedagogy. The field of scientific research — social pedagogy, educational quality management.

\begin{abstract}
In recent years a strategy of high quality education has been established in education policy, stimulating the adoption of transparent education quality assessment system, the basic component of which is internal / external audit. In practice, though, it is observed that teachers lack motivation to participate in internal audit activities, therefore, danger arises for implementation of strategic educational provision. That stimulated a research in 2006, aiming at revelation and analysis of motivating factors for teachers' participation within activities of internal audit. A quantitative design (survey) was chosen for the research. The sample was composed in two regions of the country by employing the method of cluster sampling. Altogether 589 teachers participated in the research. Quantitative data were analyzed by employing methods of factor and correlation analysis, Chi-square and Anova tests were chosen to identify differences.
\end{abstract}

During the research, five factors that motivated teachers 'participation in the internal audit activities were identified: 1) a wish to self-assess the situation of education in one's school; 2) the principal's demonstrated trust in teachers; 3) the opportunity of choice provided to the teachers; 4) the opportunity for self-expression provided to the teachers; and 5) financial incentives. The teachers with longer term of teaching experience were more motivated to participate in the internal audit activities by the trust demonstrated by the school principal than their less experienced colleagues. Financial incentives for the participation in the internal audit activities and the opportunity of choice tended to motivate women more than men. In the analysis of the teachers' attitudes to internal audit, three groups of attitudes were singled out: 1) internal audit was a meaningless and boring activity, imposed upon teachers, that did not improve the quality of the school performance; 2) internal audit meant extra work for teachers; and 3) internal audit was indispensable for the school performance, however, it had organizational shortcomings. The majority of the teachers tended to view internal audit as extra work (93\%). During the research, we established an essential relationship between the negative view of internal audit and the direct motives of the participation in the internal audit activities: the direct motivation to participate in the internal audit of those teachers who took a negative view of the said audit was weaker. The more teachers participate in the activities of internal audit the stronger their negative attitude towards it becomes. Increase of this negative attitude may witness inadequate reward for the job performed. Teachers' expectations are mostly related to financial remuneration for participation in activities of internal audit - such expectations are typical of $1 / 3$ of the respondents. On the other hand, our research also established the relationship between a negative view of internal audit and indirect motives of the participation in the internal audit activities. The teachers who took a negative view of internal audit less frequently tended to indicate that they were motivated to participate in the internal audit activities by the wish to deserve the principal's trust or the need for self-expression and choice. Another managerial problem as established in the research was the organizational dimension: 46\% of the respondents stated that internal audit was indispensable, however, it had organizational shortcomings.

Results of the research allow to conclude that teachers' motivation to participate in activities of internal audit is mostly related to the management of the process. Adequate remunaration and more efficient organization of internal audit as well as the management of the personnel (teachers) ought to improve teachers' motivation to participate in the activities of internal audit.

Keywords: teachers' motivation, internal audit at school, educational quality.

\section{INTRODUCTION}

$\mathrm{T}$ he current time is characterised by daily quality revolution: each organization seeks to make quality products and to offer quality services (Beckford, 1998; Stoner et al., 2001). Although the ideas and methods of quality management were first applied in business organizations, the quality philosophy mentioned above has been also increasingly gaining a foothold in education. Not accidentally the UNESCO emphasized the significance of quality education for the present and the future, that quality education was considered to be a priority in the European educational policy, and that in 2002, the European Council formulated the aim for the EU education 
and training systems to become a quality benchmark for the rest of the world before 2010. The 3rd Praha Forum, devoted to European education reforms, stated that European countries had been paying increasingly greater attention to the quality component in the national and local educational policies (Michel, 2003). In 2001 the European Parliament recommended the EU member states to introduce a transparent education quality assessment system and to promote internal and external audit. Internal audit at schools is regarded as a means of education services quality improvement.

Internal audit at schools is understood as a continuous process of reflection that involves all divisions and staff of the school, that seeks to look into different aspects of school performance, to identify the strengths and weaknesses of the school, to design performance improvement plans and to improve the quality of the services provided by the school. The methodology of internal audit of schools has already been successfully applied in some countries of the European Union for several years. However, the new member states are just starting to implement the methodology mentioned above and they meet with a number of common problems, the solution of which requires research.

One of those countries is Lithuania. Lately, the topicality of quality management in the Lithuanian system of education has considerably grown. Several years ago, gradual implementation of the methodology of internal audit of schools started in the country: the methodology was designed by national experts of education policy after the Scottish model. Initially, the staff of schools was taught the methodology of internal audit and, after that, schools had to assess one chosen aspect of management quality. Since 2004, internal audit has been compulsory for all comprehensive schools.

The research of the last few years witnessed that teachers generally lacked professional motivation (Atkinson, 2000; Jesus, Lens, 2005). Teachers had been observed to lack motivation for the participation in internal audit, they had doubts about the use of the internal audit methodology, and considered internal audit to be a rather complex methodology of establishing, assessing, and improving the quality of the education system. Teachers who were insufficiently motivated were not able to efficiently participate in the process of internal audit and thus put the strategic aims of improving the quality of education under threat. Therefore, practical education management faced a topical problem: how should teachers be motivated to get involved in the internal audit activities and employ the internal audit as a tool for essential improvement of the quality of education?

\section{THEORETICAL CONTEXT OF THE RESEARCH}

Job motivation is understood as a power that generates work-related behaviour and conditions the form, direction, intensity, and duration of such behaviour (Pinder, 1998). Motivation is a psychological process the result of which is determined by the interaction of an individual and the environment (Latham, Pinder, 2005). The research into staff motivation is of special interest to management specialists, as the latter consider staff motivation to be the basis of improvement of efficient managerial practice (Steers et al., 2004). However, the motivation problem was first thoroughly analyzed by psychologists.

A. Maslow was the first researcher who proposed a theory of motivation. The core idea of A. Maslow's theory of needs (1954) was the following: the basis of an individual's motivation was a hierarchical complex of needs. Maslow classified all human needs into several groups and displayed them in a hierarchical order, from the lower levels (psychological, physiological) to the top (selfactualization). Having met the needs of the lower order, individuals sought self-actualization and started looking for the meaning of their activity and the opportunities of development. Another needs theory was developed by D. McClelland (1971). The basic idea of his theory stated that an individual was simultaneously affected by several interrelated needs, with two predominant ones: that of power, the need to control one's environment, and that of achievement. With A. Maslow and $\mathrm{D}$. McClelland focussing on the differences of individual motivation in their theories, F. Herzberg (1966) sought to find out how the staff and their performance were motivated by the character of work. Herzberg proved that job motivation greatly depended on how much the job was instrinsically challenging and provided opportunities for recognition and promotion.

A different approach to job motivation developed in the 50s. That period was called the golden age of job motivation theories by R. Ste- 
ers, R. Mowday, D. Shapiro (2004), as there had never been such a big leap in the explanation of job motivation. As previous theories (A. Maslow, D. McClelland, and F. Herzberg) identified job motivation factors in a rather static environment and mainly focussed on the motivational power of human needs, the new theoreticians of job motivation looked at the issue from the dynamic viewpoint and focussed on the impact of time and events on the staff motivation. Probably the best known theory among the new ones was the cognitive expectancy theory, with V. Vroom (1964) recognized as its author. On the basis of Lewin's idea that activity was purposeful and largely based on conscious intentions, Vroom identified that the attractiveness of the task and the time invested in the task greatly depended on the individual's understanding of the significance of the outcome obtained upon the completion of the task. Another cognitive theory, that of equity, belonged to S. Adams (1963). He suggested that people always weighed their input into the task and the output, the result obtained, and they also compared their own result vis-à-vis that of other people obtained on the basis of similar input. The resulting outcome could be a salary, status, or promotion; the input could be skills, knowledge, total work record, general experience, or education. If there was a balance in the centre of the lever, equity prevailed, and the individual would continue to work hard. One more dynamic motivation theory was offered by Locke (1968). In accordance with his goal setting theory, an individual set goals and acted purposefully to achieve them. The greater the goal was, the more effort was invested. Further research (Earley, Erez, 1991) proved that participation in the formulation of the goals gave the staff the possibility to test themselves, and the process of achieving the goals motivated the efforts of both an individual and the team.

To summarize, one could state that currently there were several staff motivation theories, well justified and of great theoretical and practical value. However, R. Steers, R. Mowday and D. Shapiro (2004) discovered that, starting with the $80 \mathrm{~s}$ of the 20th century, the attention to the staff motivation issue had significantly decreased. The decrease in the attention to further development of the staff motivation theories would look strange under the new conditions of economics, globalization, and e-business. Under the new conditions motivated staff members are considered to be the strategic wealth of an organization. Therefore, heads of organizations feel an acute demand for new staff motivation models and the development of motivation theories. The need for new motivation models is also obvious in the system of education because this system has lately been undergoing essential changes.

How do researchers respond to the increasing demand for the explanation of teachers' motivation and for finding efficient motivation management models? The analysis of scientific publications resulted in establishing the following trends of teacher motivation studies: 1) the relationship between teachers' motivation and learners' learning motivation; 2) the relationship between teachers' motivation and educational reforms; and 3) teachers' job satisfaction. The researchers who studied the relationship between the teachers' motivation and the pupils' learning motivation stated that teachers' motivation made a significant impact on the pupils' learning motivation: the more motivated the teacher was, the more motivated the pupils were going to be (e. g., Lucas, 1994; Massy et al., 1994; Atkinson, 2000; Jesus, Lens, 2005). The researchers established a direct relationship between teachers' motivation and the success of educational reforms (e. g., Ofoegbu, 2004; Jesus, Lens, 2005): more motivated teachers took a more positive view of educational reforms and were more active in the practical implementation of reform goals. Teachers' job satisfaction got considerable attention from researchers. C. Ostroff (1992), T. Fong (2003) proved that less job-satisfied teachers were less motivated to work with pupils. Regretfully, the majority of teachers were found to be not happy with their jobs (Bishay, 1996). Among those satisfied with their jobs were teachers - leaders (Holloway, 2003), teachers of private schools (Perie et al., 1997), women and less experienced staff (Ma, Mac Millan, 1999), and teachers enjoying the support of school authorities (Perie et al., 1997; Ma, MacMillan, 1999).

In the analysis of scientific literature, no works were discovered on the subject of the motivation of comprehensive school teachers to participate in the activities of internal audit: that implies a novel character of the subject of the present article. The practical significance and scientific novelty of the issue encouraged the authors of the article to choose teachers' motivation to participate in 
internal audit as the object of the research. The aim of the article was to disclose and analyze the factors that motivate teachers to participate in the internal audit activities.

During the research, it was essential to establish the factors that motivated teachers to participate in the internal audit activities, however, in accordance with V. Vroom's (1964) theory which stated that the employee's performance and motivation strongly depended on his / her understanding of the significance of the task performed, it seemed reasonable to look into value-based attitudes of teachers to internal audit.

The analysis of scientific literature witnessed the relationship between teachers' job motivation and some socio-demographic characteristics (Perie et al., 1997; Ma, MacMillan, 1999; Teresevičiené, Tandzegolskienè, 2001; Holloway, 2003; Morise, Murray, 2003 and others): therefore, the authors were encouraged to look into the relationship between the factors motivating participation in the internal audit activities and the attitudes to internal audit on the one hand, and some sociodemographic characteristics of teachers, such as sex, teaching experience, the duration of participation in the audit activities, and the qualification category on the other hand.

Given the above named considerations, the research sought to find answers to the following problem questions: What factors motivate teachers' participation in the activities of internal audit? What are teachers' attitudes to internal audit? What is the relationship between the motivating factors and attitudes to internal audit and teachers' sex, teaching experience, qualification category, and the duration of participation in internal audit? What is the relationship between the motivating factors and the attitudes to internal audit?

\section{RESEARCH METHODOLOGY}

Quantitative research (survey) was carried out. The sample was composed in two stages by means of cluster sampling. All comprehensive schools were considered to be clusters with similar characteristics. In the first stage two districts were selected randomly. In the second stage part of the schools in these districts were selected randomly, and then all the teaching staff of those schools were interrogated. The total of 585 teachers took part in this survey.
In designing the questionnaire a pilot research was conducted to find out what stimulated teachers to participate in the internal audit activities and what teachers' attitudes to the internal audit were. 60 teachers answered the questions: "What stimulates you to participate in the internal audit activities?" and "What are the teachers' views of internal audit?" The analysis of the data obtained allowed to summarize the answers in 25 statements that reflected the motives of the teacher participation in internal audit and 15 statements that reflected teachers' different views on internal audit. The views and the motives became the basis of the questionnaire. Each motive and each view was to be assessed by the respondents on a 5 point ordinal scale, from 1 - "I totally disagree" - to 5 - "I totally agree". The respondents were requested to present some personal data: sex, teaching experience, the duration of the participation in the internal audit activities, and the qualification category.

To disclose the factors of teachers' participation in the internal audit activities and the teachers' principal views on internal audit, the factor analysis was carried out. To establish the differences between different respondent groups, Chi-square and Anova tests were employed, and to establish the relationships between the variables the correlational analysis was used (Spearman's rank order and Cramer's V correlation coefficients were calculated).

\section{RESULTS}

The KMO measure (0.911) and Bartlett test of sphericity $(p=0.000)$ indicated that statements were perfectly suitable for the factor analysis. By means of the factor analysis, five factors were extracted that explained $60 \%$ of the variance. The five factors extracted were: 1) the opportunity to assess the educational situation in one's own school; 2) the trust demonstrated by the school authorities; 3 ) the opportunities of choice; 4) the opportunities of self-expression; and 5) financial incentives.

In accordance with the respondents' answers, the best motivating factor was the opportunity to assess the educational situation in the school (58 to $80 \%$ of the respondents marked the constituent items of that factor as significant); the least motivating factor was the opportunity of self-expression (marked by merely $30 \%$ of the respondents), 
and the remaining three factors were medium motivating.

To establish the relationship between the factors motivating teachers' participation in the internal audit activities and the sex, teaching experience, and qualification category of the respondents, the Cramer's V test was conducted. A statistically significant relationship between F 2 (i. e. the principal's demonstrated trust in teachers) and the respondents' teaching experience was established: in case of longer teaching experience, the trust in teachers demonstrated by the principal provided a better stimulus to participate in the internal audit activities (Cramer's $\mathrm{V}=0.409 ; \mathrm{p}=0.000)$. The opportunity of choice provided to the teachers and financial incentives motivated male and female staff members in a different way. There was a weak tendency of financial incentives (F 5) and the opportunity of choice (F 3) being of greater importance for women than for men.

Teachers' attitude to internal audit also played a significant motivating role. After testing the appropriateness of the attitude scale for the factoring, it was established that the KMO measure was very high: 0.918; Bartlett test of sphericity is significant $(p=0.000)$. Consequently, the teachers' attitudes to internal audit were suitable for the factor analysis. During the factoring three factors were extracted that explained $58 \%$ of the variance: 1) internal audit was a meaningless and boring activity, imposed upon teachers, that did not improve the school performance quality; 2) internal audit meant extra work for teachers; and 3) internal audit was indispensable for the school performance, however, it had organizational shortcomings. Judging from the respondents' answers, the majority ( $93 \%$ of all respondents) considered it to be extra work. The idea that audit was an indispensable process in the school performance and that it had organizational shortcomings, was supported by $46 \%$ of the respondents. The first attitude boasted medium support: $56 \%$ of the respondents thought internal audit was imposed upon teachers, $49 \%$ found no encouragement for the participation in the internal audit activities, $46 \%$ believed that the school community did not take the internal audit assessment seriously, 46\% stated that teachers merely wasted time on internal audit, and $41 \%$ were sure that internal audit was a stupid adult game. We failed to establish the factor of positive attitudes to internal audit, as all the three factors expressed either negative or sceptical attitudes to internal audit.

To establish the relationship between the groups of respondent attitudes to internal audit and their sex, teaching experience, qualification category a Cramer's V test was carried out but no relationship was established. Statistically significant relationship was established merely in the case of the teachers' experience of the participation in internal audit activities. Using ANOVA test it turned out that the longer the teachers participated in the internal audit activities, the more they believed that internal audit was a meaningless and boring activity, imposed upon teachers, that did not improve the school performance quality $(\mathrm{F}=3.079 ; \mathrm{p}=0.028)$.

By using Spearman's rank order correlation coefficient, we sought to establish the relationships between the factors motivating teachers to participate in the internal audit activities and the teachers' attitude to internal audit. We established a tendency that a weaker attitude to internal audit as a meaningless and boring activity, imposed upon teachers, that did not improve the school performance quality, was typical of the respondents who were stronger motivated to participate in the internal audit activities by the following factors: *the opportunity to self-assess the situation of education in their school ( $r$ o $=0.517 ; \mathrm{p}=0.000)$; $*$ the principal's trust in teachers ( $r h o=0.189$; $\mathrm{p}=0.014) ; *$ the opportunity of choice provided to the teachers (rho $=0.197 ; \mathrm{p}=0.025) ;{ }^{*}$ the opportunity for self-expression provided to the teachers (rho $=0.174 ; p=0.008)$. We established the following weak tendency: teachers who believed that internal audit meant merely extra work for teachers were less frequently motivated to self-assess the educational situation at their school during internal audit ( $\mathrm{rho}=0.189 ; \mathrm{p}=0.013$ ), they were also less motivated to demonstrate their skills during internal audit ( $r h o=0.143 ; p=0.032$ ), and they less frequently sought the trust demonstrated by the school authorities $(0.289 ; \mathrm{p}=0.032)$.

\section{DISCUSSION}

The first factor (i. e. wish to self-assess the situation of education in one's school) could be considered as direct, since internal audit was introduced to schools with the aim of enabling teachers, by means of their participation in the process of internal audit, to find out the real state 
in all the fields of school activities, to be able to make decisions and participate in planning school development, and, consequently, to feel greater responsibility for school performance and better education quality. As many as $80 \%$ of the respondents stated that their participation in the internal audit activities was motivated by the wish to assess their own work and to find out whether the school was able to ensure quality education. Therefore, the direct motive of internal audit was significant for the majority of teachers.

Other motivating factors could be regarded as indirect: by participating in the activities of internal audit, teachers sought financial incentives, trust of the school authorities, and / or the opportunities for self-expression and choice. From the viewpoint of the theories of needs (A. Maslow, D. McClelland), one could state that participation in the school internal audit activities contributed to the teachers' satisfaction of their personality needs. The topicality of the latter needs in teachers' motivation was also stated in the works of other researchers. Thus, e. g., M. Teresevičiene, J. Tandzegolskienè (2001) and A. Palujanskienè (2002) stated that the need for esteem, recognition and for self-actualization had a great impact on the motivation of teachers' activities. The results of the research suggested that teachers with longer term of teaching experience were more motivated to participate in the internal audit activities by the trust demonstrated by the school principal than their less experienced colleagues. Financial incentives for the participation in the internal audit activities and the opportunity of choice tended to motivate women more than men.

In the analysis of teachers' attitudes to internal audit, three groups of attitudes were singled out: 1) internal audit was meaningless and boring activity, imposed upon teachers, that did not improve the quality of school performance; 2) internal audit meant extra work for teachers $(93 \%)$; and 3 ) internal audit was indispensable for the school performance, however, it had organizational shortcomings (46\%). We failed to identify any positive views of internal audit: all the three factors expressed merely negative or sceptical views on it. Thus, teachers' views on internal audit witnessed their lack of understanding of its significance.

During the research, we established an essential relationship between the negative view of internal audit and the direct motives of the participation in the internal audit activities: the direct motivation to participate in the internal audit of those teachers who took a negative view of the audit was weaker. That meant that, in comparison with their colleagues, they were less motivated to self-assess the educational situation in their school and to improve it. Consequently, the failure to understand the significance of internal audit made a negative impact on teachers' direct motivation to participate in the internal audit activities. The conclusion complied with V. Vroom's (1964) theory where the author stated that the failure to understand the significance of the work performed had an adverse effect on the work performance and its motivation.

In this context, a specific fact established in the research deserved attention: the said negative view was related to the experience of the teachers' participation in the internal audit activities; the more years the teacher participated in the audit, the more negative he / she tended to become about it. Participation in the internal audit activities several years ago was a new and challenging task for teachers. That kind of activity, according to F. Herzberg's theory, was able to generate teachers' satisfaction and strong motivation, provided they were adequately remunerated. The teachers' ever increasing negative view of internal audit might bear witness to inadequate remunaration to the teachers for the work performed.

On the other hand, our research also established the relationship between a negative view of internal audit and indirect motives of the participation in the internal audit activities. Teachers who took a negative view on internal audit less frequently tended to indicate that they were motivated to participate in the internal audit activities by the wish to deserve the principal's trust or the need for self-expression and choice. One could assume that the negative view of internal audit was partly formed by the lack of trust in teachers on the part of the school authorities. The trust of the school authorities could serve as a non-financial reward to the teachers for their participation in internal audit, however, when the trust was not demonstrated, the satisfaction with the work disappeared, and the motivation, and, consequently, quality work performance, tended to weaken. The fact that the teachers missed the trust in them demonstrated by the school principal bore witness to the shortcomings in the managerial style of the school authorities. In the theory of management, staff motivation 
was considered to be one of the major management functions. Inefficient performance in that field resulted in a negative impact on the staff motivation and performance quality. Provided the problem identified was considered as an opportunity to improve the managerial activities, school principals ought to be recommended to pay more attention to teachers' motivation to participate in internal audit, and primarily, to demonstrate greater trust in teacher participants of internal audit, especially in those with longer teaching records.

Another managerial problem as established in the research was the organizational dimension: $46 \%$ of the respondents stated that internal audit was indispensable, however, it had organizational shortcomings. The fact mentioned above bore witness to another function - organizational being inefficiently performed by school authorities. Therefore, the attention of school principals ought to be drawn to the improvement of the organizational function performance.

To summarize, one could conclude that teachers' motivation to participate in the internal audit activities was greatly related to the management of the internal audit process. Adequate remuneration and efficient organization of internal audit, as well as effective staff management, ought to strengthen teachers' motivation to participate in the internal audit activities.

\section{REFERENCES}

Adams, S. (1963). Towards an understanding of inequity. Journal of Abnormal and Social Psychology, 67, 422-436.

Atkinson, E. S. (2000). An investigation into the relationship between teacher motivation and pupil motivation. Educational Psychology, 20 (1), 45-58.

Beckford, J. (1998). Quality: A Critical Introduction. London: Routledge.

Bishay, A. (1996). Teacher Motivation and Job Satisfaction: A Study Employing the Experience Sampling Method. Internet link: http://hcs.harvard.edu/ jus/0303/bishay.pdf Earley, P., Erez, M. (1991). Time dependency effects on goals and norms: The role of cognitive processing on motivational models. Journal of Applied Psychology, 76, $717-727$

Fong, T. (2003). The Importance of Teacher Job Satisfaction and its Implications. Internet link: http:// www.columbia.edu/ af2011/AIR_Paper.pdf

Herzberg, F. (1966). Work and the Nature of Man. Cleveland: World Publishing.

Holloway, J. M. (2003). Sustaining experienced teachers. Educational Leadership, Vol. 60 (8), 87-93.

Jesus, S., Lens, W. (2005). An integrated model for the study of teacher motivation. Applied Psychology: An International Review, 54 (1), 119-134.

Latham, G., Pinder, C. (2005). Work motivation theory and research at the dawn of the twenty-first century. Annual Review of Psychology (56), 485-516.

Locke, E. A. (1968). Toward a theory of task motivation and incentives. Organizational Behavior and Human Performance, 3, 157-189.

Lucas, A. F. (1994). Strengthening Departmental Leadership: A Team-Building Guide for Chairs in Colleges and Universities. San Francisco: Jossey-Bass Publisher.

Ma, X., MacMillan, R. B. (1999). Influences of workplace conditions on teachers' job satisfaction. Journal of Educational Research, 93 (1), 39-47.
Maslow, A. (1954). Motivation and Personality. New York: Harper \& Row.

Massy, W. F., Wilger, A. K., Colbeck, C. (1994). Overcoming "Hoolowed" collegiality. Change, 26 (4), $10-20$.

McClelland, D. (1971). Assessing Human Motivation. New York: General Learning Press.

Michel, A. (2003). Standartu gerinimas: diskusijos ir realybè. Švietimo sistemos pokyčiu standartai ir strategijos. Pranešimas trečiajame Prahos forume. Prieiga per internetą: http://www.mtp.smm.lt/dokumentai/ InformacijaSvietimui/uzsStraipsniuVertimai/ prahos.doc

Morice, L., Murray, J. (2003). Compensation and teacher retention: A success story. Educational Leadership, 60, $40-48$

Ofoegbu, F. (2004). Teacher motivation: A factor for classroom effectiveness and school improvement in Nigeria. College Student Journal, 38 (1), 81-89.

Ostroff, C. (1992). The relationship between satisfaction, attitude and performance: An organizational level analysis. Journal of Applied Psychology, 77, 963-974.

Palujanskienè, A. (2002). Vidinè profesijos pedagogo motyvacija darbo veikloje. Pedagogika, 59, 111-116.

Perie, M., Baker, D., Whitener, S. (1997). Job Satisfaction Among America's Teachers: Effects of Workplace Conditions, Background Characteristics, and Teacher Compensation. NCES: Statistical Analysis Report.

Pinder, C. (1998). Work Motivation in Organizational Behaviour. Upper Saddle River, NJ: Prentice Hall.

Steers, R., Mowday, R., Shapiro, D. (2004). The future of work motivation theory. Academy of Management Review, 29 (3), 379-387.

Stoner, J., Freeman, R., Gilbert, D. (2001). Vadyba. Kaunas: Poligrafija in informatika.

Teresevičienė, M., Tandzegolskienė, I. (2001). Mokytojų darbo motyvacijos ypatumai. Pedagogika, 50, 12-21.

Vroom, V. (1964). Work and Motivation. New York: Wiley. 


\title{
MOKYTOJŲ DALYVAVIMO VIDAUS AUDITO VEIKLOJE MOTYVACIJA KAIP UGDYMO KOKYBĖS VEIKSNYS
}

\author{
Liudmila Rupšienè, Vilija Targamadzė \\ Klaipédos universitetas, Klaipéda, Lietuva
}

\begin{abstract}
SANTRAUKA
Pastaraisiais metais švietimo politikoje itvirtinama kokybiško išsilavinimo strategija, skatinama idiegti skaidrią švietimo kokybės vertinimo sistemą, kurios svarbiausia sudedamoji dalis yra vidaus ir išorès auditas. Praktikoje pastebima, kad mokytojai stokoja motyvacijos dalyvauti vidaus audito veikloje ir dèl to kyla grèsmé strateginių švietimo nuostatų igyvendinimui. Tai paskatino $2006 \mathrm{~m}$. atlikti tyrimą, kuriuo buvo siekiama atskleisti ir išnagrinèti mokytojų dalyvavimo vidaus audito veikloje motyvuojamuosius veiksnius. Tyrimui buvo pasirinktas kiekybinis metodas (apklausa raštu). Imtis buvo sudaryta tikimybinès dvipakopès lizdinès atrankos būdu dviejuose šalies regionuose. Iš viso tirti 589 mokytojai.

Tyrimo metu išskirti penki veiksniai, kurie skatina mokytojus dalyvauti vidaus audito veikloje: siekis isivertinti ugdymo situaciją savo mokykloje; mokyklos vadovo demonstruojamas pasitikejjimas mokytojais; mokytojams suteikiamos pasirinkimo galimybės; mokytojams suteikiamos saviraiškos galimybė; materialinis skatinimas. Didesni pedagoginio darbo stažą turinčius mokytojus labiau negu mažiau patyrusius kolegas dalyvauti vidaus audito veikloje skatina mokyklų vadovų demonstruojamas pasitikèjimas mokytojais. Materialinis skatinimas už dalyvavimą vidaus audito veikloje ir pasirinkimo galimybès kiek dažniau motyvuoja moteris negu vyrus.

Analizuojant mokytojų nuostatas į vidaus auditą, buvo išskirtos trys grupès: 1) vidaus auditas beprasmis, neįdomus, per prievartą igyvendinamas, negerinantis mokyklos veiklos kokybės mokytojų darbas; 2) vidaus auditas yra papildomas mokytoju darbas; 3) vidaus auditas - būtinas mokyklos veikloje, tačiau turintis daug organizavimo trūkumų. Didžioji dauguma mokytojų (93\%) mano, kad auditas — papildomas darbas.

Tyrimo metu nustatėme esmini ryšị tarp neigiamų nuostatu i vidaus auditą ir tiesioginių dalyvavimo vidaus audito veikloje motyvų - neigiamai nusiteikusių vidaus audito atžvilgiu mokytojų tiesioginė motyvacija dalyvauti šioje veikloje yra silpnesnè. Kuo daugiau metų mokytojai dalyvauja vidaus audito veikloje, tuo labiau stiprẻja jų neigiama nuostata į vidaus auditą. Mokytojų neigiamų nuostatų i vidaus audita stiprejimas gali liudyti apie neadekvatų mokytojų atlyginimą už nuveiktą darba.

Tyrimo rezultatai leidžia manyti, kad mokytoju motyvacija dalyvauti vidaus audito veikloje didžiaja dalimi yra susijusi su vidaus audito proceso valdymu. Adekvatus materialinis apmokejjimas, efektyvesnis vidaus audito organizavimas ir mokytojų personalo valdymas turètų sustiprinti mokytojų motyvaciją dalyvauti vidaus audito veikloje.
\end{abstract}

Raktodžiai: mokytojų motyvacija, mokyklos vidaus auditas, ugdymo kokybė.

Gauta 2006 m. rugsèjo $12 \mathrm{~d}$.

Received on September 12, 2006

Priimta 2006 m. gruodžio $6 \mathrm{~d}$.

Accepted on December 6, 2006
Liudmila Rupšienė

Klaipėda University

(Klaipèdos universitetas)

S. Neries str. 5, LT-92223, Klaipeda

Lithuania (Lietuva)

Phone +37046398637

E-mail liudarupsiene@rupeksa.com 